\title{
Psychological Stress and its Relationship to Marital Adjustment among Working Mothers in Jordanian Society and its Impact on Raising Children
}

\author{
Dr. Nader Fahmi ALZyoud ${ }^{1}$ \\ ${ }^{1}$ Department OF Educational Psychology and Counselling Psychology, Faculty of Educational Science, The \\ Hashemite University, Jordan \\ Correspondence: Dr. Nader Fahmi ALZyoud, Department OF Educational Psychology and Counselling \\ Psychology, Faculty of Educational Science, The Hashemite University, Jordan
}

Received: January 6, 2020

Accepted: February 20, 2020

Online Published: February 24, 2020

doi:10.5539/ijps.v12n1p10

URL: https://doi.org/10.5539/ijps.v12n1p10

\begin{abstract}
This study was aimed to investigate the relationship between psychological stress and marital adjustment among working mothers in Jordanian society and its impact on raising children in order to achieve the objectives of the study, the researcher used the qualitative and quantitative methods, employing the questionnaire survey tool. The study population consisted of all working mothers in Jordanian society. The study sample consisted of 72 working mothers. The data were analyzed using Statistical Package for the Social Sciences (SPSS.24).

The researcher found that there is a level of psychological stress and marital adjustment among working mothers in Jordanian society, the statistical analysis showed that there is no relationship between psychological stress and marital adjustment among working mothers. The results show that there is impact of psychological stress on raising children among working mothers. The researchers recommend Carrying out pre-marital training programs for those who are about to get married to raise awareness about marital life and marital harmony and its impact on family children, and the need for the working mother to pay attention to the social aspect of her children and encourage them to continue social communication.
\end{abstract}

Keywords: psychological stress, working mothers, Jordanian society, raising children

\section{Introduction}

If our modern era is characterized by the era of pressure and anxiety, given the tremendous technological development, civilization acceleration and social change that generally strained man with his endless requirements, then working women are considered a network of pressures. Working women play many roles and bear heavy burdens, they work in a public body or institution, and they bear the problems and pressures of this job, including the troubles and constraints that burden women. As a result of this, and in many cases, working women suffer from problems such as stress, fatigue and various health problems, in addition to psychological suffering such as anxiety, stress and frustration. All of these negative effects left by the work pressure are carried by the woman to her house, leaving in turn the obvious impact on the husband and children (Waite et al., 2009).

The contemporary family suffers from many challenges and complicated problems in an era that is filled with pressures in various fields of life. Perhaps family security today is one of the most complex challenges that must be addressed. Working for the safety of the family is an urgent social necessity required by the developmental needs of society at various levels. Yüksel and Dağ (2015) clarified that building a healthy family and ensure its safe durability sustainability requires the presence of two partners who are compatible, and who understand the meanings of partnership, marriage, and family, and who are aware of the influential changes and transformations that contemporary life presents (Krishnan, 2014). In light of these crises, marital adjustment in married life has become one of the aspirations that every married individual in society seeks to have.

Although work gives women the opportunity to achieve themselves and empty their potentials, and it gives them the opportunity to exercise different roles; however, previous studies have unanimously agreed that there are problems experienced by working women; some of which relate to job burdens and the role conflict of reconciling the responsibilities of domestic work and work Career (Waite et al., 2009). Some see that work places the prospects of women and develops their personality, and contributes to increasing the level of national 
income and enhancing the economic level of the family. Others believe that working women live in a state of tension, stress and excitement at home and at work, due to the assumption of multiple responsibilities that contribute to not enabling them to achieve compatibility between their work and good education for their children (Mutlu et al., 2017). Consequently, the multiplicity of opinions and their divergence necessitates the need to conduct a modern study that supports the results of previous studies. Accordingly, the current study seeks to investigate the relationship between psychological stress and marital adjustment among working mothers in Jordanian society and its impact on raising children.

\subsection{Research Problem}

Previous studies revealed the existence of problems that a working woman suffers from (Al-Omari, 2005; Al-Zadjali, 2009; Pisula and Porębowicz-Do“rsmann, 2017). Some of these problems are related to the job aspect, and some are related to her struggle in an attempt to achieve reconciliation between her responsibilities at home and at work, while others are related to the customs and traditions imposed on women in society. Studies have differed in their findings regarding the effects of work on a woman's duties and her family life (Renu,2017).

Some studies have shown that a woman's work contributes to creating problems in her marital life. A woman may neglect her husband on the pretext of not having enough time, and raising her children may be neglected or transferred the task of raising them to the maid or elderly grandparents, which leads to an increase in the level of problem between the spouses (Butzer and Konstantareas, 2003; Asma, 2015; Yüksel and Dağ, 2015). Other studies have shown that work contributes to strengthening ties with the husband (Al-Omari, 2005), and the study of Al-Zadjali (2009) concluded that a working woman is a leading woman and she is able to prevent any conflict between work and her responsibility towards her family. Consequently, the difference in the results of the studies confirms the need to conduct more recent studies that can deny or prove the findings of previous studies. Thus, the current study necessarily seeks to investigate the relationship between psychological stress and marital adjustment among working mothers in Jordanian society, Moreover, this study seeks to find the effect of psychological stress of working mothers in Jordanian society on raising children.

\subsection{Research Questions}

The problem of this research can be summarized in the following questions:

1. What is the level of psychological stress among working mothers in Jordanian society?

2. What is the level of marital adjustment among working mothers in Jordanian society?

3. What is the relationship between psychological stress and marital adjustment among working mothers in Jordanian society?

4. How does the psychological stress of working mothers in Jordanian society affect raising children?

\subsection{Research Importance}

Psychological stress is one of the topics of great importance in contemporary life, especially in the last decades of the last century due to the complexity of social life, and its patterns that regulate the social interaction and civilization acceleration. All of these are factors that have caused the emergence of various phenomena that require greater efforts to adapt to their renewed demands, which made them pressure factors whose effects vary on individuals and groups in society and thus become the most common and widespread pressures of life, which made them the area of interest of scientists and researchers to deepen their research on them.

Offering a topic of this kind is extremely important, because it addresses a socio-family research problem that concern the individual, the family, and even society, with the theoretical knowledge it provides that raises people's awareness of marriage, marital and family adjustment issues. This research sheds light on the foundations of family stability, permanence and ways of reaching the urgent needs, it has to understand the elements of marital adjustment, and this is closely related to family and societal security, especially after increasing levels of family disintegration, actual and spiritual divorce, and high rates of family violence in contemporary society.

The current study also provides important knowledge for many official social institutions, civil and working, and which are interested in caring for the family, and children, and for academic specialists, and the Arab and international library, especially as it deals with dimensions and variables that have a relationship and direct impact on the Jordanian family. 


\section{Literature Review}

\subsection{Psychological Stress}

Psychological stresses are the group of stimuli that the individual is exposed to in addition to the responses that result from it. Psychological stresses also include the individual's assessment of the level of risk, and the methods of adapting to the psychological pressures and defenses used by the individual in such circumstances. Pisula and Porębowicz-Do"rsmann (2017) stressed that the field of psychological stress includes physiological, social and psychological aspects. They argued that the pressure has a bilateral relationship between the individual and the environment, where the individual affects the environment and is affected by it.

Psychological stresses are defined as the physical and psychological exhaustion that affects an individual and is caused by various life events which limits an individual's ability to face obstacles and challenges (Roberts et al., 2014). Hayes and Watson (2013) defined psychological pressures as a large group of difficulties and problems facing a person, whether internal, emotional, psychological, environmental, or civilizational.

Many studies indicated the negative effects that psychological pressures have on women in general, including (Singh, M., Singlh, 2006; Roberts et al., 2014):

1. The low level of the quality of maternal care they provide to children.

2. Superficial emotional relationship with family members

3. Inability to reconcile the different roles they play

4. Feeling guilty and tired

5. Low level of physical and psychological immunity

6. Inability to perform the life roles expected of them

Exposure of women to pressure may reflect negatively on their emotional aspects, in terms of rapid arousal, frustration and increased anxiety, pessimism, depression, fear, feelings of loss of control, and low level of effectiveness (Whisman, 2001). The sources of psychological pressure have increased during the last decades in various forms, due to the changing conditions of social, professional, and family life in the family in general, and for women in particular, due to the increasing emotional disturbances that women experience with the increase in the number of marriage years, and the increase in the tasks and roles assigned to them. Butzer and Konstantareas (2003) emphasized that the family depends on a number of basic ingredients in order to be able to perform its function as a social institution, and the safety and success of the family may depend primarily on the happiness and safety of the mother's psychological and physical. There are certain circumstances that may be outside the control of the wife, affect its social status and its efficiency in caring for children and performing family-related roles (Krishnan, 2014).

Bhattacharjee and Tripathi (2012) clarified that a woman's personality may be an auxiliary factor in doubling the level of psychological stress, and there are a number of factors related to a woman's personality such as; the level of mental and physical health, the birth of a new child, divorce or separation (Bhattacharjee and Tripathi, 2012), the illness of a husband or one of the children, a lack of control, and the multiple roles that she plays (Krishnan, 2014), family problems, lack of adequate support from the other partner, attachment to children, restrictions on the maternal role, lack of experience and knowledge of childcare skills, and social isolation (Whisman, 2001).

Several studies were conducted to determine the level of psychological stress for working women. Amreya (2014) found that the level of psychological stress in various health and economic fields and in the family field is low. Hattar et al. (2008) found the high level of psychological pressure experienced by married women, and that the sources of this pressure are due to the expectations of the role that women play, and the inability of women to organize work requirements in a manner that does not conflict with the requirements of the home. Moreover, the lack of time and lack of cooperation of husbands was the main source of pressure for married women.

\subsection{Marital Adjustment}

Marital adjustment is a positive bilateral interaction between a couple based on love, affection, and the satisfaction of basic and secondary needs, without sharp differences or disturbances that affect their lives. Basharpoor and Sheykholeslami (2015) argued that marital adjustment includes marital happiness. Matrimonial adjustment is represented in the appropriate choice of marriage, a willingness to achieve and enter into marital life, mutual love between spouses, sexual gratification, assuming marital responsibilities, and the ability to solve marital problems and marital stability. Peterson-Post et al. (2014) clarified that marital adjustment is also a case 
that includes the elimination of the psychological and emotional needs of the couple, which gives psychological and emotional stability and mutual mercy, a sense of concern, a sense of responsibility, self-worth and affirmation through the performance of duties and obtaining rights (Yüksel and Dağ, 2015).

Whitson and El-Sheikh (2003) argued that for achieving the marital adjustment, each husband must work to fulfill the needs of the other party and satisfy his/her desires. They must also make each other feel positive. Basharpoor and Sheykholeslami (2015) emphasized that there are various areas of marital adjustment, which include:

1. Religious adjustment: It is an arbitration of God's religion in the rights and duties of both spouses, and this cuts off the dispute and gives happiness a space in the marital home.

2. Social and cultural adjustment: marital life includes the formation of common methods of life in eating, sleeping, spending, and earning. When the spouses belong to similar families in which similar behavioral habits prevail, the shared life becomes easy, but if both the husband and wife belong to a different social environment, the process of adjustment becomes more difficult. Yüksel and Dağ (2015) concluded that individuals with integrated characteristics enjoyed better adjustment in married life, and that couples with cultural affinity did not suffer from a higher degree of depression.

3. Love and Emotion: Mutual love is an important factor and an essential manifestation of marital adjustment, as Peterson-Post et al. (2014) mentioned that it is a requirement for the growth of the normal personality, in which there are feelings in the marriage that accompany the relationship between the spouses where they share each other, as both feel the need to meet the needs of the other party (Mutlu et al., 2017).

4. Sexual compatibility: Sex plays a very important role in an individual's life and has an effect on his/her behavior and psychological health. Sexual activity satisfies both biological needs, psychological needs and social needs for parties. Psychosexual adjustment means that each of the harmonious spouses fulfills his/her needs from the other and satisfies him/her, and therefore both parties are happy with the continuation of the relationship.

Previous studies have tested the level of marital adjustment for working women. Amreya (2014) found that the level of marital adjustment among women workers is high, especially in the axis of compatibility with the husband, and the level of adjustment with children and relatives is average. Al-Khatayba study (2015) found that the level of marital adjustment in males is higher than that of females, as this confirms the consent of wives to their husbands' performance of their practice of the various dimensions of marital adjustment in marital life.

\subsection{Psychological Stress of Working Women and Marital Adjustment}

Women are the most vulnerable members of society to psychological stress, due to the diversity and multiplicity of roles entrusted to them imposed by our Arab societies. In many cases the pressures resulting from the roles of women may exceed their ability and status. These pressures make it incapable of adapting to these pressures. These stresses also consume from women a great energy and effort in pursuit of psychological and family stability. Butzer and Konstantareas (2003) affirm that women suffer from the increasing pressures of life, and this affects their physical and psychological health, and their feelings of anxiety towards their future and the future of their children may increase. This will Make her feel family instability, insecurity, and push her to search for a safe future for herself and her family.

Asma (2015) found that there is a negative relationship between the stress resulting from the work of women and the marital adjustment of working women, as the multiplicity of roles is one of the biggest problems experienced by working women. Al-Omari study (2005) concluded that the negative effects resulting from a woman's work are represented by the woman's concern for her husband and children, in addition to the increased burden on her, which causes her many negative psychological effects such as nervousness, tension and anxiety on her career future. Yüksel and Dağ (2015) concluded that the woman expresses her psychological state in devious ways, as she begins to complain about health problems, fatigue, and absenteeism from work.

Jameh's study (2011) concluded that the double life that a working woman lives between her work and her home makes her of a different nature, where she lives her life with confidence that makes her bear all the responsibilities related to the husband, the home and the children, and she tries not to complain and is committed to performing her work in the best way.

The studies also confirmed the varying level of the husbands 'appreciation of their working wives, as a study Basharpoor and Sheykholeslami (2015) showed that the husband does not value the burdens of women and does 
not cooperate with them, while other studies indicated the high level of cooperation between the working wife and husband in making family decisions.

\subsection{Psychological Stress and its Impact on the Child}

The family is considered the most important factors of education and socialization, it is contributed to shape the personality of the individual and determine his behavior and principles. The family can contribute greatly to the social development of the child and social culture. Whitson and El-Sheikh (2003) stated that the family has a very important psychosocial function; it is the child's first social school, and it contributes to the child's psychological fulfillment and proper psychological construction.

Exposing the child to painful experiences will affect the child's future outlook, his tolerance to life's problems and his ability to solve these problems. Negative experiences contribute to the negative impact on the personality of the child, which makes him vulnerable to infection with various mental illnesses and psychological contract. Mutlu et al. (2017) added that the nature of the relationship between the parents is considered another influencing factor on the child's personality. If the relationship was bad, it certainly leads to the disintegration of the family, which creates an unhealthy atmosphere that leads to the affect the child's development, psychological development. Yüksel and Dağ (2015) clarified that the psychological problems of the parents lead to instability in the family atmosphere, as it affects the mental health of the child and leads to improper psychological development of the child. Basharpoor and Sheykholeslami (2015) emphasized that the bad psychological state of the mother may be the cause of the child's affliction with many diseases, as this condition is reflected on the child and he will become vulnerable to many mental illnesses such as depression, emotional tension and a feeling of permanent anxiety.

Opinions differ on the effect of women's work on raising children. Some indicate that the problems that a working woman is exposed to depend on the type of woman and the type of relationship she has with her children. Her work may offer children the opportunity to collaborate and learn at home and depend on themselves, or her work may impose heavy burdens on the children that only adults can bear (Yüksel and Dağ, 2015). Whitson and El-Sheikh (2003) emphasized that the presence of the mother in the home does not guarantee the success of her relationship with her husband and children, as the long time that the mother spends with her children is not considered evidence of good motherhood, so if a woman has a strong desire to work and feels that her children are holding her from achieving that, then her relationship with them will be negatively affected to a large extent.

Al-Daheri (2008) study conducted in a group of Arab countries indicated that $78 \%$ of children did not have any difficulty in the work of the mother, while $15 \%$ suffered from loneliness and depression during the absence of the mother, and $4 \%$ complained about conflicts between the parents and was caused by the work of the mother in first degree.

\section{Research Methodology}

\subsection{Study Tools}

\subsubsection{The Dyadic Adjustment Scale}

A 27-item scale designed to measure relationship satisfaction. The Dyadic Adjustment Scale (DAS) is a revised version of the original Dyadic Adjustment Scale (Spanier, 1976). The researcher also depended on the DAS scales of Busby et al. (1995); Prouty et al. (2000) used in their studies. The revised version offers improved psychometric properties, is shorter, and includes only 3 of the original 4 subscales:

- Dyadic Consensus: the degree of compatibility between the respondent and the partner

- Dyadic Satisfaction: the degree of satisfaction between the respondent and the partner

- Dyadic Cohesion: degree to which respondent and partner participate in activities together.

\subsubsection{Psychological Stress Scale}

The researcher used a 9-element scale designed to measure psychological stress. and This scale depended on Several scales were used in a study Lemyre et al. (1990) and Lemyre, L. and Tessier (2003). To examine the study hypotheses, the researcher used the following statistical methods:

- Arithmetic averages and standard deviations; to know the respondents' level of response and to indicate the extent of dispersion from the mean.

- The Alpha Cronbach test.

- The Correlation test. 


\section{- The One-Sample t.test.}

\subsubsection{A Questionnaire to Determine the Impact of Psychological Stress on Raising Children}

To investigate the aim of this research, a quantitative approach was used and in this case, a questionnaire survey method is the most appropriate to be conducted. The participants in this research are the working mothers in Jordanian society.

The researcher has adopted in designing the questionnaire on previous studies and articles related to the subject of the current research, where the researcher has depended on them to choose the right statements which suit the nature of the current research. In addition, the researcher has adopted in designing the questionnaires on the results of the preliminary study.

The research population consists of working mothers in Jordanian society. Therefore, the researcher relied on a random sample of 72 working mothers.

\subsection{Data Analysis}

This section presents the findings of the study that aims to investigate the relationship between psychological stress and marital adjustment among working mothers in Jordanian society and its impact on raising children. In addition, this part includes the answer to questions.

The researcher tested 72 working mothers completed survey, which was collected from the randomly selected sample.

\subsection{Reliability Analysis}

The researcher has distributed the questionnaire on sample pilot of study (72 respondents) and computes extents questionnaire reliability by calculation of internal consistency using Cronbach' alpha values, table 1 show that:

Table 1 . The result of reliability

\begin{tabular}{lccc}
\hline No & Variables & $\begin{array}{c}\text { Cronbach's } \\
\text { Alpha }\end{array}$ & Item No \\
\hline 1 & The Dyadic Adjustment Scale (DAS) & 0.750 & 27 \\
2 & Psychological stress measure (PSM) & 0.675 & 9 \\
3 & The impact of Psychological stress on raising children & 0.912 & 11 \\
Psychological stress and its relationship to marital adjustment among working mothers in & 0.766 & 47 \\
\hline
\end{tabular}

Table 1 shows that the reliability of the Dyadic Adjustment Scale (DAS) is equal to 0.75, the reliability of the Psychological stress measure (PSM) is equal to 0.68, and reliability of the impact of Psychological stress on raising children is equal to 0.91 . The total alpha values of Psychological stress and its relationship to marital adjustment among working mothers in Jordanian society and its impact on raising children reached (0.77). This indicates to accept reliability. Othman (2001) mentioned in this research that the coefficient of reliability (Cronbach's alpha) that can be adopted is from 0.65 to 0.85 .

\subsection{Descriptive Analysis}

\subsubsection{Demographic Profile of Respondents}

The demographic profile of the respondents in the research is presented in table 2 to 4 below. A questionnaire was designed to analyses the Psychological stress and its relationship to marital adjustment among working mothers in Jordanian society and its impact on raising children in this study (see Appendix 1) to gather primary data. The questionnaires were then distributed to (72) of working mothers in Jordanian.

The following is a description of the members of the study sample according (age, Experience, and Qualification), as in following Tables: 


\subsubsection{Age}

Table 2. Distribution of the sample according to age

\begin{tabular}{cccc}
\hline Variable & Categories & Frequency & Percent \\
\hline below 30 years & 12 & 16.7 \\
Age & 30-40 years & 13 & 18.1 \\
& $41-50$ years & 17 & 23.6 \\
& more than 50 years & 30 & 41.7 \\
Total & 72 & 100.0
\end{tabular}

Table 2 shows that presents the profile of the respondents in terms of their age; there are 30 respondents, $41.7 \%$, who are in the age more than 50 years. Another 17 respondents, $23.6 \%$ whose age between $41-50$ years, $18.1 \%$ lie between age limit of 30 to 40 years, $16.7 \%$ lie age limit of below 30 years.

\subsubsection{Experience}

Table 3. Distribution of the sample according to experience

\begin{tabular}{cccc}
\hline Variable & Categories & Frequency & Percent \\
\hline \multirow{2}{*}{ less than or equal to 3 years } & 35 & 48.6 \\
3 years-5 years & 22 & 30.6 \\
& 5 years- 10 years & 11 & 15.3 \\
more than 10 years & 4 & 5.6 \\
& Total & 72 & 100.0
\end{tabular}

The results indicate that (35) respondents had experience of less than or equal to 3 years, Their percentage thim (48.6\%). In addition to Another (22) respondents, Their percentage thim (30.6\%). The results also indicate (11) respondents had experience ranges from 5 to 10 years, By (15.3\%). with the remaining (5.6\%) of respondents have more than 10 years.

\subsubsection{Qualification}

Table 4. Distribution of the sample according to Qualification

\begin{tabular}{|c|c|c|c|}
\hline Variable & Categories & Frequency & Percent \\
\hline \multirow{7}{*}{ Qualification } & Technical/ vocational certificate & 31 & 43.1 \\
\hline & Diploma & 18 & 25.0 \\
\hline & Bachelor's degree & 14 & 19.4 \\
\hline & Post graduate/ master's degree & 4 & 5.6 \\
\hline & $\mathrm{PhD}$ & 1 & 1.4 \\
\hline & Post-doctoral & 4 & 5.6 \\
\hline & Total & 72 & 100.0 \\
\hline
\end{tabular}

Table 4 shows the qualification, it is worth pointing out that most of the respondents Technical/ vocational certificate at a percentage $43.1 \%$. However, the lowest categories $(\mathrm{PhD})$ by frequency (1) percentage $1.4 \%$. 


\subsubsection{Answer to Questions}

\subsubsection{Question One: What is the Level of Psychological Stress Among Working Mothers in Jordanian Society?}

To answer this question and to detect the level of psychological stress among working mothers in Jordanian society, the arithmetic means and standard deviations were used for all the paragraphs of the Psychological stress measure (PSM); the tables below shows that.

The descriptive analysis was computed for each item. The Table no. (5) Below, reveals the components means and standard deviation.

Table 5. Means and standard deviation for "Psychological stress measure (PSM)" items and total means of them $(\mathrm{n}=72)$

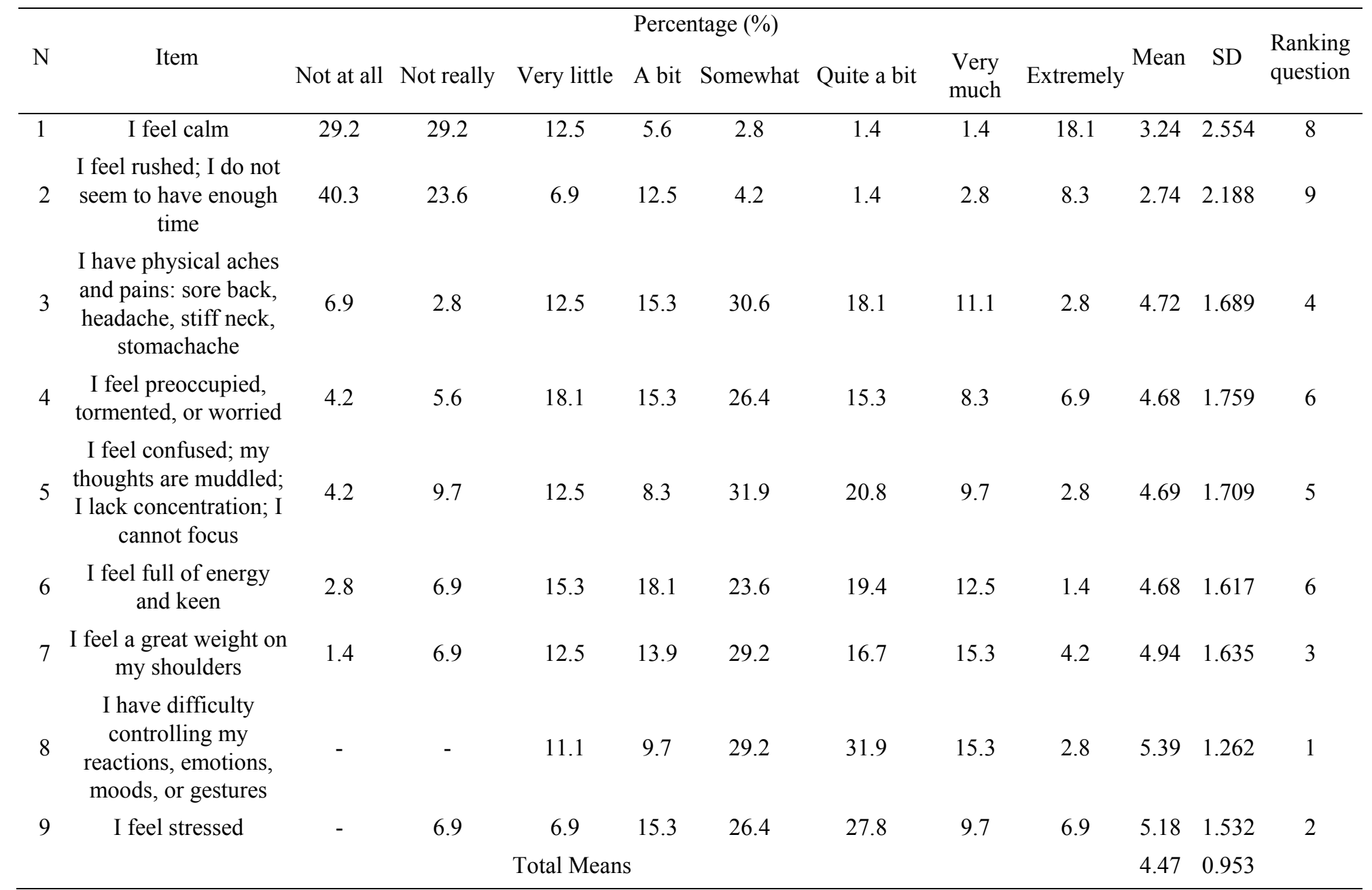

Table 4.7 shows that the arithmetic means of paragraphs "Psychological stress measure (PSM)" ranging from (2.74-5.39), and most notably the highest means reached (5.39) out of (8) for the item (8) "I have difficulty controlling my reactions, emotions, moods, or gestures", and then for the item (9) "I feel stressed" (means 5.18). And the lowest means was (2.74) for the item (2) "I feel rushed; I do not seem to have enough time".

All respondents were often with the level of psychological stress among working mothers in Jordanian society, and the total means reached (4.47) and standard deviation (0.95).

3.4.2.2 Question Two: What is the Level of Marital Adjustment Among Working Mothers in Jordanian Society?

To answer this question and to detect the level of marital adjustment among working mothers in Jordanian society, the arithmetic means and standard deviations were used for all the paragraphs of the Dyadic Adjustment Scale (DAS). the tables below showed that.

To assess the question (Q2) the level of marital adjustment among working mothers in Jordanian society. The responses for each component were recoded into the numerical value of " 1 " for minimal response to " 5 " for a maximum value of responses. 
The descriptive analysis was computed for each item. The Table 6, 7, 8 below, reveals the components means and standard deviation.

3.4.2.2.1 Dyadic Consensus Subscale

Table 6. Means and standard deviation for "Dyadic Consensus subscale" items and total means of them $(\mathrm{n}=72)$

\begin{tabular}{|c|c|c|c|c|c|c|c|c|}
\hline \multirow[b]{2}{*}{$\mathrm{N}$} & \multicolumn{8}{|c|}{ Percentage (\%) } \\
\hline & Item & $\begin{array}{l}\text { Always } \\
\text { disagree }\end{array}$ & $\begin{array}{l}\text { Frequently } \\
\text { disagree }\end{array}$ & $\begin{array}{l}\text { Occasionally } \\
\text { agree }\end{array}$ & $\begin{array}{c}\text { Almost } \\
\text { always agree }\end{array}$ & $\begin{array}{l}\text { Always } \\
\text { agree }\end{array}$ & Mean SD $\mathrm{F}$ & Rank \\
\hline 1 & Handling family finances & 11.1 & 37.5 & 18.1 & 19.4 & 13.9 & 2.881 .255 & 512 \\
\hline 2 & Matters of recreation & 5.6 & 15.3 & 22.2 & 44.4 & 12.5 & 3.431 .072 & 25 \\
\hline 3 & Religious matters & 13.9 & 20.8 & 19.4 & 27.8 & 18.1 & 3.151 .329 & 7 \\
\hline 4 & Friends & 15.3 & 22.2 & 27.8 & 19.4 & 15.3 & 2.971 .289 & 11 \\
\hline 5 & Conventionality & 11.1 & 11.1 & 18.1 & 31.9 & 27.8 & 3.541 .310 & 4 \\
\hline 6 & Philosophy of life & 15.3 & 18.1 & 22.2 & 36.1 & 8.3 & 3.041 .227 & $7 \quad 8$ \\
\hline 7 & $\begin{array}{l}\text { Ways of dealing with } \\
\text { parents or in-law }\end{array}$ & 1.4 & 11.1 & 11.1 & 26.4 & 50.0 & 4.131 .087 & $7 \quad 1$ \\
\hline 8 & $\begin{array}{l}\text { Aims, goals, and things } \\
\text { believed important }\end{array}$ & 6.9 & 9.7 & 15.3 & 30.6 & 37.5 & 3.821 .237 & 72 \\
\hline 9 & $\begin{array}{l}\text { Amount of time spent } \\
\text { together }\end{array}$ & 12.5 & 8.3 & 13.9 & 36.1 & 29.2 & 3.611 .327 & 73 \\
\hline 10 & Making major decisions & 20.8 & 18.1 & 16.7 & 30.6 & 13.9 & 2.991 .379 & 10 \\
\hline 11 & Household tasks & 25.0 & 12.5 & 15.3 & 30.6 & 16.7 & 3.011 .458 & 9 \\
\hline 12 & $\begin{array}{l}\text { Leisure time interests and } \\
\text { activities }\end{array}$ & 9.7 & 22.2 & 15.3 & 43.1 & 9.7 & 3.211 .186 & 66 \\
\hline 13 & Career decisions & 27.8 & 22.2 & 16.7 & 25.0 & 8.3 & 2.641 .346 & 513 \\
\hline & & & Total Means & & & & 3.260 .619 & \\
\hline
\end{tabular}

Shown in the table 6 that the arithmetic means of paragraphs "Dyadic Consensus subscale" ranging from (2.64-4.13), and most notably the highest means reached (4.13) out of (5) for item (7) "Ways of dealing with parents or in-law ", then for item (8) "Aims, goals, and things believed important" (means 3.82). And the lowest means was (2.64) for items (13) "Career decisions". The total mean for "Dyadic Consensus subscale" reached mean (3.26) and standard deviation (0.619). 


\subsection{Dyadic Satisfaction Subscale}

Table 7. Means and standard deviation for "Dyadic Satisfaction subscale" items and total means of them $(\mathrm{n}=72)$

\begin{tabular}{|c|c|c|c|c|c|c|c|c|c|}
\hline \multirow[b]{2}{*}{$\mathrm{N}$} & \multirow[b]{2}{*}{ Item } & \multicolumn{5}{|c|}{ Percentage (\%) } & \multirow[b]{2}{*}{ Mean } & \multirow[b]{2}{*}{$\mathrm{SD}$} & \multirow[b]{2}{*}{ Rank } \\
\hline & & Never & Occasionally & $\begin{array}{l}\text { Most often } \\
\text { than not }\end{array}$ & $\begin{array}{l}\text { Most of } \\
\text { the time }\end{array}$ & $\begin{array}{l}\text { All the } \\
\text { time }\end{array}$ & & & \\
\hline 1 & $\begin{array}{l}\text { How often do you discuss or have you } \\
\text { considered divorce, separation, or } \\
\text { terminating your relationship? }\end{array}$ & 12.5 & 13.9 & 22.2 & 30.6 & 20.6 & 3.33 & 1.300 & 8 \\
\hline 2 & $\begin{array}{l}\text { How often do you or your mate leave the } \\
\text { house after a fight? }\end{array}$ & 8.3 & 12.5 & 18.1 & 37.5 & 23.6 & 3.56 & 1.221 & 5 \\
\hline 3 & $\begin{array}{l}\text { In general, how often do you think that } \\
\text { things between you and your partner are } \\
\text { doing well? }\end{array}$ & 1.4 & 12.5 & 16.7 & 36.1 & 33.3 & 3.88 & 1.061 & 1 \\
\hline 4 & Do you confide in your mate? & 9.7 & 6.9 & 16.7 & 37.5 & 29.2 & 3.69 & 1.241 & 3 \\
\hline 5 & $\begin{array}{l}\text { Do you ever regret that you married? (or } \\
\text { lived together) }\end{array}$ & 11.1 & 16.7 & 8.3 & 38.9 & 25.0 & 3.50 & 1.332 & 7 \\
\hline 6 & How often do you and your partner quarrel? & 6.9 & 9.7 & 9.7 & 47.2 & 26.4 & 3.76 & 1.157 & 2 \\
\hline 7 & $\begin{array}{l}\text { How often do you and your mate "get on } \\
\text { each other's nerves?" }\end{array}$ & 11.1 & 4.2 & 19.4 & 43.1 & 22.2 & 3.61 & 1.205 & 4 \\
\hline \multirow[t]{2}{*}{8} & Do you kiss your mate? & 4.2 & 20.8 & 13.9 & 41.7 & 19.4 & 3.51 & 1.151 & 6 \\
\hline & \multicolumn{3}{|c|}{ Total Means } & & & & 3.61 & 0.668 & \\
\hline
\end{tabular}

Shown in the table 7 that the arithmetic means of questions " Dyadic Satisfaction subscale" ranging from (3.33-3.88), and most notably the highest means reached (3.88) out of (5) for question (3) " In general, how often do you think that things between you and your partner are doing well?", then for question (6) " How often do you and your partner quarrel?" (Means 3.76). In addition, the lowest means was (3.33) for question (8) "How often do you discuss or have you considered divorce, separation, or terminating your relationship?" The total mean for "Dyadic Satisfaction subscale" reached mean (3.61) and standard deviation (0.668).

\subsection{Dyadic Cohesion Subscale}

Table 8. Means and standard deviation for "Dyadic Cohesion subscale" items and total means of them $(n=72)$

\begin{tabular}{|c|c|c|c|c|c|c|c|c|c|}
\hline \multirow[b]{2}{*}{$\mathrm{N}$} & \multicolumn{9}{|c|}{ Percentage (\%) } \\
\hline & Item & Never & Rarely & Occasionally & $\begin{array}{l}\text { Most every } \\
\text { day }\end{array}$ & Every day & Mean & $\mathrm{SD}$ & Rank \\
\hline 1 & $\begin{array}{l}\text { Do you and your mate engage in outside } \\
\text { interests together? }\end{array}$ & - & 11.1 & 12.5 & 50.0 & 26.4 & 3.92 & 0.915 & 3 \\
\hline 2 & Have a stimulating exchange of ideas? & 4.2 & 8.3 & 12.5 & 47.2 & 27.8 & 3.86 & 1.052 & 4 \\
\hline 3 & Laugh together? & 4.2 & 4.2 & 11.1 & 52.8 & 27.8 & 3.96 & 0.971 & 2 \\
\hline 4 & Calmly discuss something? & 4.2 & 18.1 & 11.1 & 45.8 & 20.8 & 3.61 & 1.133 & 5 \\
\hline \multirow[t]{2}{*}{5} & Work together on a project? & 4.2 & 5.6 & 8.3 & 45.8 & 36.1 & 4.04 & 1.027 & 1 \\
\hline & & 1 Means & & & & & 3.88 & 0.730 & \\
\hline
\end{tabular}

Shown in the table 8 that the arithmetic means of questions" Dyadic Cohesion subscale" ranging from (3.61-4.04), and most notably the highest means reached (4.04) out of (5) for question (5)" Work together on a project?", then for question (3) "Laugh together?" (Means 3.96). And the lowest means was (3.61) for questions (4) "Calmly discuss something?" The total mean for "Dyadic Cohesion subscale" reached mean (3.88) and standard deviation (0.73). 
3.4.2.3 Question Three: What is the Relationship between Psychological Stress and Marital Adjustment Among Working Mothers in Jordanian Society?

To answer this question and to detect the relationship between psychological stress and marital adjustment among working mothers in Jordanian society, were accomplished using the bivariate analysis, in which a parametric test such as Pearson correlation was engaged through analysis. The results of the correlation test represent in table 9.

Table 9. Correlation between psychological stress and marital adjustment

\begin{tabular}{ccc}
\hline & psychological stress \\
\hline marital adjustment & Pearson Correlation & -.109 \\
Sig. (2-tailed) & $\mathrm{N}$ & .364 \\
& $* *$. Correlation is significant at the 0.01 level (2-tailed). \\
\hline
\end{tabular}

According to the results shown in the table of the correlation test, find that there is a relationship between psychological stress and marital adjustment, it is a strong effect of the correlation coefficient; since the correlation coefficient is equal 0.109 between the psychological stress and marital adjustment among working mothers in Jordanian society.

3.4.2.4 Question Four: How does the Psychological Stress of Working Mothers in Jordanian Society Affect Raising Children?

To answer this question and to detect the impact of psychological stress among working mothers in Jordanian society on raising children, the one-sample t.test was used, and to answer this question and to detect the psychological stress of working mothers in Jordanian society affect raising children, the arithmetic means and standard deviations was used for all the paragraphs; the tables below shows that.

Table 10. One- Sample t.test results of the overall average to effect of psychological stress on raising children

\begin{tabular}{cccccccc}
\hline & No & Mean & SD & Std. Error Mean & DF & t-Value & Sig. \\
\hline $\begin{array}{c}\text { effect of psychological stress } \\
\text { on raising children }\end{array}$ & 72 & 4.022 & 0.7562 & 0.08912 & 71 & 45.123 & 0.000 \\
\hline
\end{tabular}

Table 10 shows that there is a statistically significant for the impact of psychological stress among working mothers in Jordanian society on raising children at a significant level $(\alpha \leq 0.05)$, where "t" value reached (45.123) by statistically significant $(0.00)$, which indicates the effect of psychological stress on raising children among working mothers in Jordanian. 
Table 11. Means and standard deviation for "The impact of Psychological stress on raising children" items and total means of them $(n=72)$

Percentage (\%)

\begin{tabular}{|c|c|c|c|c|c|c|c|c|c|}
\hline $\mathrm{N}$ & Item & $\begin{array}{l}\text { Strongly } \\
\text { disagree }\end{array}$ & Disagree & $\begin{array}{c}\text { To some } \\
\text { extent (but } \\
\text { not certain) }\end{array}$ & Agree & $\begin{array}{l}\text { Strongly } \\
\text { agree }\end{array}$ & Mean & SD & Rank \\
\hline 1 & Instability of family atmosphere & 2.8 & 2.8 & 4.2 & 44.4 & 45.8 & 4.28 & .892 & 1 \\
\hline 2 & $\begin{array}{l}\text { Negative impact on the child's personality } \\
\text { due to the constant use of punishment } \\
\text { methods }\end{array}$ & 1.4 & 5.6 & 6.9 & 54.2 & 31.9 & 4.10 & .858 & 2 \\
\hline 3 & $\begin{array}{l}\text { Inability to satisfy the child's psychological } \\
\text { desires }\end{array}$ & 5.6 & 2.8 & 6.9 & 52.8 & 31.9 & 4.03 & 1.007 & 7 \\
\hline 4 & $\begin{array}{l}\text { Inability to build a child's psychological } \\
\text { well-being }\end{array}$ & 2.8 & 9.7 & 5.6 & 50.0 & 31.9 & 3.99 & 1.014 & 8 \\
\hline 5 & $\begin{array}{l}\text { Continuous nervousness in dealing with } \\
\text { children }\end{array}$ & 4.2 & 11.1 & 9.7 & 47.2 & 27.8 & 3.83 & 1.088 & 11 \\
\hline 6 & Neglecting children & 5.6 & 8.3 & 8.3 & 45.8 & 31.9 & 3.90 & 1.115 & 9 \\
\hline 7 & Lack of safe child care in the home & 1.4 & 8.3 & 11.1 & 37.5 & 41.7 & 4.10 & .995 & 2 \\
\hline 8 & Depriving the child of emotion & 6.9 & 11.1 & 5.6 & 41.7 & 34.7 & 3.86 & 1.214 & 10 \\
\hline 9 & $\begin{array}{l}\text { The decline of the academic educational } \\
\text { levels of children }\end{array}$ & 4.2 & 6.9 & 6.9 & 43.1 & 38.9 & 4.06 & 1.060 & 4 \\
\hline 10 & $\begin{array}{c}\text { The constant absence of children from the } \\
\text { home }\end{array}$ & 6.9 & 2.8 & 9.7 & 38.9 & 41.7 & 4.06 & 1.124 & 4 \\
\hline 11 & The child's constant feeling of anxiety & 4.2 & 2.8 & 12.5 & 45.8 & 34.7 & 4.04 & .985 & 6 \\
\hline \multicolumn{7}{|c|}{ Total Means } & 4.02 & .756 & \\
\hline
\end{tabular}

Table 11 shows that the arithmetic means of paragraphs " The impact of Psychological stress on raising children " ranging from (3.83-4.28), and most notably the highest means reached (4.28) out of (5) for the item (1) " Instability of family atmosphere ", then for the items (2), (7) " Negative impact on the child's personality due to the constant use of punishment methods", " Lack of safe child care in the home " (means 4.10). And the lowest means was (3.83) for the item (5) "Continuous nervousness in dealing with children ".

All respondents were agreed with the impact of Psychological stress on raising children, and the total means reached (4.02) and standard deviation (0.756).

\section{Conclusion}

The results show that there is the level of psychological stress and marital adjustment among working mothers in Jordanian society, the statistical analysis shown that no relationship between psychological stress and marital adjustment among working mothers. The results show that there impact of psychological stress on raising children among working mothers.

These results have been strengthened through various prior researches' results, such as Yüksel and Dağ (2015) that the psychological problems of the parents lead to instability in the family atmosphere, as it affects the mental health of the child and leads to improper psychological development of the child. Basharpoor and Sheykholeslami (2015) emphasized that the bad psychological state of the mother may be the cause of the child's affliction with many diseases, as this condition is reflected on the child and he will become vulnerable to many mental illnesses such as depression, emotional tension and a feeling of permanent anxiety.

Butzer and Konstantareas (2003) affirm that women suffer from the increasing pressures of life, and this affects their physical and psychological health, and their feelings of anxiety towards their future and the future of their children may increase.

This agree with study Asma (2015) found that there is a negative relationship between the stress resulting from the work of women and the marital adjustment of working women, as the multiplicity of roles is one of the biggest problems experienced by working women. 


\section{Recommendations}

The current research highlighted the Psychological stress and its relationship to marital adjustment among working mothers in Jordanian society and its impact on raising children, nevertheless, further investigation is essential to confirm and verify the results of this study. Through previous results, the researcher recommends the following:

- Carrying out pre-marital training programs for those who are about to get married to raise awareness about marital life and marital harmony and its impact on family children.

- The need for the working mother to pay attention to the social aspect of her children and encourage them to continue social communication.

- Attention to the care of working mothers and the continued provision of support to them, by their families, which leads to the creation of appropriate mental health for their children.

- Providing a suitable work environment for working mothers free from stress, this reflects positively on the home and family.

\section{References}

Al- Daheri, S. (2008). The basics of marital and family counseling. Amman, Safaa House for Publishing and Distribution.

Al-Khatiba, Y. (2015). Elements of adjustment in married life and its relationship to social factors: a study on a sample of husbands working in government schools in northern Jordan. studies. Humanities and Social Sciences, 24(2), 371-899.

Al-Omari, Q. (2005). Image of Omani women working in youth culture, 1st floor, Sultanate of Oman, Eastern Press.

Al-Zadjali, K. (2009). Omani women's empowerment and societal challenges. Master study. Ain Shams University, Egypt.

Amreya, M. (2014). The Self-Concept Dimensions of the Employed and Unemployed Women and its Relationship with the Level of Stress and Family Adjustment in the Dakhlia Governorate. Master thesis in Education, specialization in psychological counseling. University of Nizwa.

Asma, E. (2015). Occupational pressures and their relationship to marital compatibility for working women, fields study on a sample of nurses and teachers in the Tolga department in the governorate of Biskra. $\mathrm{PhD}$ thesis in Psychology, majoring in Social Psychopathology.

Basharpoor, S., \& Sheykholeslami, A. (2015). The Relation of Marital Adjustment and Family Functions With Quality of Life in Women. Eur J Psychol, 11(3), 432-441. https://doi.org/10.5964/ejop.v11i3.859

Bhattacharjee, S., \& Tripathi, P. (2012). A study on psychological stress of working women. ZENITH International Journal of Multidisciplinary Research, 2(2), 434-438.

Busby, D., Christensen, C., Crane, R., \& Larson, J. (1995). A Revision of the Dyadic Adjustment Scale for Use with Distressed and Nondistressed Couples: Construct Hierarchy and Multidimensional Scales. Journal of Marital and Family Therapy, 21(3), 289-308. https://doi.org/10.1111/j.1752-0606.1995.tb00163.x

Butzer B., \& Konstantareas MM. (2003). Depression, temperament and their relationship to other characteristics in children with Asperger's disorder. J Dev Disabl, 10, 67-72.

Hattar, P., Meleis, M., \& Nagib, H. (2008). Multiple role stress and patterns of camping of Egyptian women in clerical jobs. Journal of trans - Cultural Nursing, 14(2), 125-133. https://doi.org/10.1177/1043659602250633

Hayes SA., \& Watson SL. (2013). The impact of parenting stress: a meta-analysis of studies comparing the experience of parenting stress in parents of children with and without autism spectrum disorder. $J$ Autism Dev Disord, 43, 629-42. https://doi.org/10.1007/s10803-012-1604-y

Jameh, M. (2010). Family sociology, marital compatibility analysis and family violence. Alexandria, the new university publishing house.

Krishnan, L. (2014). Factors Causing Stress among Working Women and Strategies to Cope Up. Journal of Business and Management (IOSR-JBM), 16(5). e-ISSN: 2278-487X, p-ISSN: 2319-7668. https://doi.org/10.9790/487X-16551217 
Lemyre, L., \& Tessier, R. (2003). Measuring psychological stress. Concept, model, and measurement instrument in primary care research, 49 . Canadian Family Physician $\bullet$ Le Médecin de famille canadien.

Lemyre, L., Tessier, R., \& Fillion,L. (1990). La Mesure du stress psychologique: manuel d'utilisation. Québec, Que: Behaviora.

Mutlu, B., Erkut, Z., Yildırım, Z., \& Gündoğdu, N. (2017). A review on the relationship between marital adjustment and maternal attachment. Rev Assoc Med Bras 2018, 64(3), 243-252. https://doi.org/10.1590/1806-9282.64.03.243

Peterson-Post K. M., Rhoades G. K., Stanley S. M., \& Markman H. J. (2014). Perceived criticism and marital adjustment predict depressive symptoms in a community sample. Behavior Therapy, 45(4), 564-575. https://doi.org/10.1016/j.beth.2014.03.002

Pisula, E., \& Porębowicz-Do“rsmann, A. (2017). Family functioning, parenting stress and quality of life in mothers and fathers of Polish children with high functioning autism or Asperger syndrome. PLoS ONE, 12(10), 1-19. https://doi.org/10.1371/journal.pone.0186536

Renu, P. (2017). Marital adjustment among working and non-working married women. International Journal of Home Science, 3(1), 384-386.

Prouty, A., Markowski, E., \& Barnes, H. (2000). Using the Dyadic Adjustment Scale in Marital Therapy: An Exploratory Study. THE FAMILY JOURNAL: COUNSELING AND THERAPY FOR COUPLES AND FAMILIES, 8(3), July 2000 250-257. https://doi.org/10.1177/1066480700083006

Roberts, R., Muller, T., Sweeney, B., gannoni, a., \& Bralkovic, C. (2014). Promoting psychological well - being in women with phenylketonuria: pregnancy related stresses, coping strategies and supports. Molecular genetics and Metabolism Reports, 1, 148-157. https://doi.org/10.1016/j.ymgmr.2014.03.002

Singh, M., \& Singlh G. (2006). A Comparison Of Mental Health Status During Menopause And Post-Menopause Middle-Aged Working Women. The Internet Journal of World Health and Societal Politics, 4(1), 88-95. https://doi.org/10.5580/5fe

Spanier, G. B. (1 976). Measuring dyadic adjustment: New scales for assessing the quality of mar-rage and similar dyads. Journal of Marriage and the Family, 38, 15-28. https://doi.org/10.2307/350547

Waite L. J., Luo Y., \& Lewin A. C. (2009). Marital happiness and marital stability: Consequences for psychological well-being. Social Science Research, 38, 201-212. https://doi.org/10.1016/j.ssresearch.2008.07.001

Whisman, M. A. (2001). The association between depression and marital dissatisfaction. In S. Beach (Ed.), Marital and family processes in depression: A scientific approach (pp. 3-24). Washington, DC: American Psychological Association. https://doi.org/10.1037/10350-001

Whitson S., \& El-Sheikh M. (2003). Marital conflict and health: Processes and protective factors. Aggression and Violent Behavior, 8, 283-312. https://doi.org/10.1016/S1359-1789(01)00067-2

Yüksel, O., \& Dağ, I. (2015). The Relationship Between Marital Adjustment and Psychological Symptoms in Women: The Mediator Roles of Coping Strategies and Gender Role Attitudes. Turk psikiyatri dergisi $=$ Turkish journal of psychiatry, 26(3), 181-188.

\section{Copyrights}

Copyright for this article is retained by the author(s), with first publication rights granted to the journal.

This is an open-access article distributed under the terms and conditions of the Creative Commons Attribution license (http://creativecommons.org/licenses/by/4.0/). 